\title{
Hội đồng Nghiên cứu Úc bị chỉ trích dữ dội vì chính sách bất hợp lý với preprints
}

- sciencevietnam $\quad$ Khoa học lý thú (1) August 26, 2021

ENHANCED BY Google

SSHPA (26-08-2021) —Trong tháng 7 vừa qua, việc nhiều trường đại học Úc tuyên bố sẽ cắt giảm ngành Khoa học Xã hội và Nhân văn đã gặp phải các phản ứng mạnh mẽ từ cộng đồng. Sự căng thẳng giưa cộng đồng khoa học tại Úc và các nhà hoạch định chính sách lại tiếp tục gia tăng vì quyết định từ chối mọi hồ sơ tài trợ khoa học có đề cập tới preprint.

Theo Nature đưa tin [1], Australian Research Council sẽ từ chối tất cả mọi hồ sơ xin tài trợ khoa học có đề cập tới preprint ở bất cứ phần nào của hồ sơ. Đây được coi là cập nhật từ quy định trước đây, vốn chỉ cấm việc đưa preprint vào danh sách xuất bản chính thức. Với quy định này, có ít nhất khoảng 20 nhà nghiên cứu đã bị từ chối tài trợ

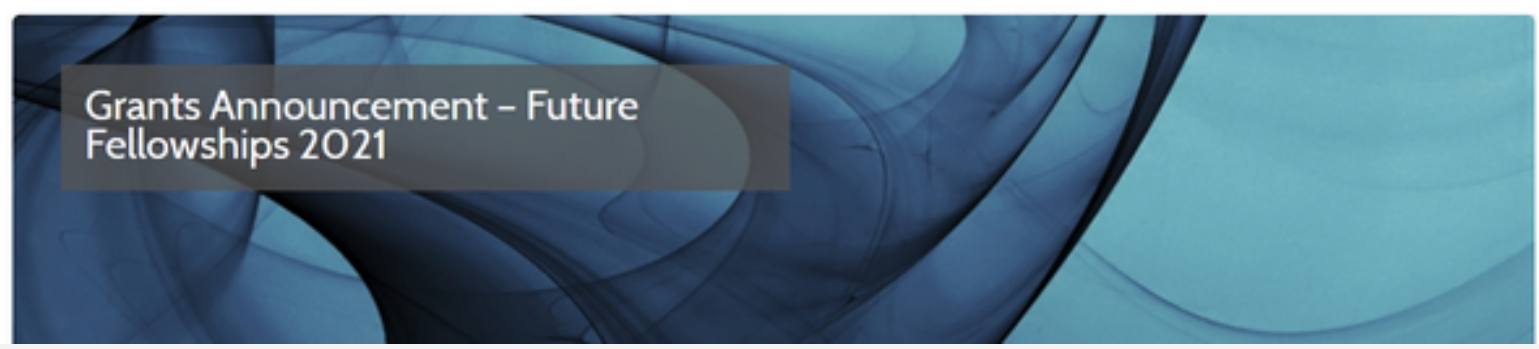

Xét trong bối cảnh preprint ngày càng trở nên quan trọng trong hệ sinh thái xuất bản khoa học, quy định này được coi là một động thái 'giết chết sự đổi mới' [1]. Đối với nhiều ngành khoa học tự nhiên, các hệ thống preprint như arXiv (vật lý, toán học) hay medRxiv (sinh y) còn được ưa chuộng hơn là các tạp chí truyền thống. Trong đại dịch COVID-19 vừa qua, vai trò của các hệ thống preprint rõ ràng là không thể chối bỏ. Các hệ thống preprint này giúp các nhà nghiên cứu có thể công bố các kết quả mới một cách nhanh nhất, đồng thời giúp công chúng có thể tiếp cận và hiểu giá trị khoa học một cách dễ dàng hơn [2].

Hiện nay, ngay cả các xuất bản phẩm chính thức có phản biện cũng không tránh khỏi các nghi vấn về chất lượng, và vấn đề rút bài cũng xuất hiện thường xuyên hơn [3]. Sự đa dạng của hệ thống xuất bản khoa học vì thế giúp mang tới khả năng kiểm soát chất lượng và cập nhật tốt hơn. 
Tài liệu tham khảo:

[1] Watson C. (2021). Preprint ban in grant applications deemed 'plain ludicrous'.

Nature, doi: 10.1038/d41586-021-02318-8

[2] Vuong QH. (2018). The (ir)rational consideration of the cost of science in transition economies. Nature Human Behaviour, 2(1), 5.

[3] Vuong QH. (2020). Reform retractions to make them more transparent. Nature, 582(7811), 149.

(1) Last modified: 8/28/2021 3:00 PM

(-) Views: 7

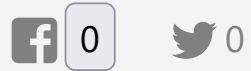

Bài liên quan:

- Lấy trứng chọi đá: Liệu tạp chí khoa học có bị thay thế bởi preprint?

- COVID-19 và thế giới xuất bản học thuật

- Lịch sử hình thành các kho lưu trữ dữ liệu

- Tìm kiếm cơ hội học bổng cho giai đoạn đầu sự nghiệp

- Các trường đại học phải hỗ trợ tốt hơn cho các nhà nghiên cứu trẻ, nếukhông sẽ bị cắt tài trợ

Ý kiến bạn đọc (0):

Comment

Gửi bình luận

(C) 2018 - 2021 EASE Vietnam SciComm System. All rights reserved. Powered by Vuong \& Associates.

Built to serve the social sciences and humanities. 